\title{
ВЕРБАЛІЗАЦІЯ НЕВЕРБАЛІКИ: КОМПАРАТИВНО-ЗІСТАВНИЙ АНАЛІЗ НАЦІОНАЛЬНОЇ ПОВЕДІНКИ (на матеріалі української, російської, польської фразеології)
}

\author{
ТЕТЯНА ОСІПОВА \\ Харківський національний педагогічний університет імені Г. С. Сковороди, \\ Харків - Україна \\ ostaniya1967@gmail.com; ORCID: 0000-0003-2899-2606 \\ WERBALIZACJA W KOMUNIKACJI NIEWERBALNEJ: \\ KOMPARATYWNO-PORÓWNAWCZA ANALIZA ZACHOWAŃ NARODOWYCH \\ (na materiale ukraińskiej, rosyjskiej i polskiej frazeologii) \\ TETIANA OSIPOWA \\ Charkowski Narodowy Uniwersytet Pedagogiczny imenia Hryhorija Skoworody, \\ Charków - Ukraina
}

STRESZCZENIE. W artykule przeanalizowano metodykę badań nad parametrami komunikacji niewerbalnej, werbalizowanymi poprzez jednostki frazeologiczne ukraińskiego, polskiego, rosyjskiego etnosu, które łączą wspólne wschodniosłowiańskie korzenie. Zastosowanie komparatywno-porównawczej metody analizy sprzyja ujawnieniu pragmatycznych mechanizmów tworzenia komunikacyjnych znaczeń frazeologizmów z komponentami niewerbalnymi.

Słowa kluczowe: parametry narodowe, komunikacja niewerbalna, werbalizacja, jednostka frazeologiczna, składnik niewerbalny, metoda komparatywno-porównawcza, mechanizmy pragmatyczne, znaczenie komunikacyjne.

\section{VERBALIZATION OF NON-VERBAL: COMPARATIVE CONTRASTIVE ANALYSIS \\ OF NATIONAL BEHAVIOUR (based Ukrainian, Russian, Polish Phraseology)}

\section{TETIANA OSIPOVA}

H. S. Skovoroda Kharkiv National Pedagogical University, Kharkiv — Ukraine

ABSTRACT. The article deals with the actualization of the study methodology of the nonverbal communication (NC) national parameters, verbalized by means of phraseological units $(\mathrm{PhU})$ in Ukrainian, Polish, Russian ethnoses as these that have common eastern Slavic roots. The use of the comparative contrastive method of analysis facilitated the process of revealing the pragmatic mechanisms of the communicative senses of phraseological units with the non-verbal components.

Key words: national parameters, non-verbal communication, verbalization, phraseological unit, non-verbal component, comparative contrastive method, pragmatic mechanism, communicative sense.

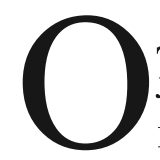

дним 3 нагальних напрямів сучасного мовознавства постає розробка лінгвометодології, що спрямована на ,з'ясування природи мови у співвідношенні зі свідомістю їі носіїв, соціумом, культурою, дійсністю, комунікацією, процесами пізнання світу, а також на формування інструментарію, засад і способів опису й аналізу мови та іiі продуктів"”.

\footnotetext{
${ }^{36}$ О. О. Селіванова, Сучасна лінгвістика : напрями та проблеми, Полтава 2008, с. 11.
} 
Теорія невербальної комунікації грунтується більшою мірою на постулатах загальної методології як учення про способи пізнання й осмислення дійсності й формування внутрішнього рефлексивного досвіду людини, а також про дослідницькі настанови, принципи та процедури аналізу об'єктів різних мов ${ }^{2}$, спрямовуючи пізнання у сферу комунікації загалом. Однак при цьому ігнорується роль мови як невід'ємної ланки загального ланцюжка мислення.

Сучасні паралінгвальні дослідження в Україні (Ю. Герасимчук, О. Гніздечко, Г. Демиденко, Л. Корнєва, Т. Космеда, Н. Коловоротна, М. Крижановська, Т. Музичук, Т. Осіпова, Л. Петровська, I. Попик, Л. Самойлович, І. Скрипник, Л. Солощук, О. Стародубцева, Н. Стрілець, 3. Чанишева та ін.) мають дещо спорадичний характер і зорієнтовані більше в площину дискурсології як „міждисциплінарної сфери знань, що міститься на перетині лінгвістики, соціології, психології, етнографії, семіотичного напряму літературознавства, стилістики і філософії”'. Наявний теоретично-описовий доробок потребує певних узагальнень, систематизації дослідних методик.

Усталені вирази (фразеологізми, прислів'я, приказки, афоризми), як відомо, найбільш яскраво відображають лінгвокультуру кожного народу, його світобачення, світовідчуття і світорозуміння, репрезентують загальнолюдські релігійні, натурфілософські, психоментальні та ін. уявлення, сприяють засвоєнню ономастикону, традицій, обрядовості, символів, репрезентують специфіку контактів між народами, національний характер тощо 4 , а отже, частково заповнюють лакуни взаєморозуміння між різними етносами; водночас, як доводять окремі аспектуальні дослідження, можуть наражати й на труднощі під час декодування. Семантика й прагматика можуть не збігатися, а потенційні трансформації зовсім переформатовувати смисли ${ }^{5}$. У сучасних міграційних умовах актуальною проблемою стає пошук паралелей взаєморозуміння з метою запобігання міжкультурних девіацій і конфліктів, що й становить актуальність зазначеної проблематики.

Специфіку національної поведінки зазвичай розглядають на матеріалі близькоспоріднених або контрастних мовних культур, застосовуючи порівняльно-історичний (або компаративний) і зіставний методи аналізу. Як відомо, зазначені методи належать до різних галузей мовознавства - порівняльноісторичної лінгвістики й зіставного мовознавства, що розв' язують протилежні за змістом завдання. Якщо порівняльний метод доводить спільність походження мов, їхню генетичну близькість, типологію ${ }^{6}$, то зіставний - поглиблює знання про одну мову на тлі іншої, не вдаючись до встановлення типологічних рис цих мов, “працює” на створення граматичних універсалій7. Спрямовані в площину комунікативної лінгвістики, зокрема в іiі невербальний сектор, ці методи реалізують одне з головних завдань лінгвометодології - обгрунтування зв'язку пізнавальної здатності людини з мовою й мовленням, процесами комунікації.

${ }^{1}$ Там само.

${ }^{2}$ А. П. Загнітко, Основи дискурсологї, Донецьк 2008, с. 9.

${ }^{3}$ Т. Космеда, О. Гоменюк, Т. Осіпова, Українська фразеологія в польській аудиторії: проблеми засвосння, [в:] Українська мова у світі, зб. матер. IV Міжнар. наук.-практ. конф. 9-10 лист. 2016 р., Львів 2016, с. 117.

${ }^{4}$ Т. Космеда, О. Гоменюк, Т. Осіпова, Короткий украйнсько-польський словник усталених виразів: еквіваленти слова, фразеологізми, прислів'я та приказки; за заг. ред. проф. Т. А. Космеди, Познань-Харків-Дрогобич 2017, с. 17-18.

${ }^{5}$ Див. про це: О. Селіванова, Сучасна лінгвістика: термінологічна енциклопедія, Полтава 2006 , с. $164-165$.

${ }^{6}$ Там само, с. 473. 
Мета цієї наукової розвідки - актуалізувати методику вивчення національних комунікативних параметрів невербальної поведінки, імпліцитно виражених мовними одиницями паремійного типу українського, польського, російського етносів як таких, що мають спільні слов'янські корені, застосовуючи компаративний і зіставний методи аналізу, що багатоаспектно висвітлюють зазначену проблематику.

Емпіричні дослідження паремійного матеріалу зазначених етносів надали можливість виявити деякі кількісні та якісні тенденції стереотипових виявів національної поведінки, репрезентованих мовними одиницями фразеологічного рівня, що вказують на генетичну близькість цих слов'янських мов.

Невербальне профілювання мовного матеріалу на предмет вербалізації (омовлення) параметрів невербальної комунікації (проаналізовано по 2000 од. найбільш поширених паремій від кожної мови) відбулося за таким кількісним розподілом: українські - 252 од. (12,6 \%); польські - 227 од. (11\%); російські - 205 од. (10\%). Зауважимо, що репрезентація невербаліки міститься в межах одного відсоткового рівня 3 незначними коливаннями, що становить інтерес у плані класифікаційного розподілу омовлення невербальних параметрів.

Зокрема однаково чи 3 незначною відмінністю омовлені кінетичні параметри ходи, постави в усіх трьох мовах - по 0,7 \%. Серед них є еквівалентні форми, напр.: Дати драпака (укр.) - Dać drapaka (noge) (пол.) - Бросаться (броситься) со всех ног (рос.); Гнути шию (укр.) - Zginać kark (пол.) Гнуть спину (горб) (рос.); Преклоняти (преклонити) коліна (укр.) - Siedzieć na karku (пол.) - Преклонить колени (рос.) і под.

Омовлення жестово-рухового комплексу невербальної комунікації (HК) коливається, порівн.: укр. - 1,5\%, пол. - $1 \%$, рос. - 1,9\%, ілюструючи найбільш поширену кінесику, що внаслідок фразеологізації репрезентує ментальні комунікативні коди. Більшою мірою їхні значення ідентичні в усіх розглядуваних мовах, порівн.: Втерти (утерти) носа (укр.) - Przytrzeć nosa (пол.) - Утереть нос (рос.); Збиратися в кулак (укр.) - Brać się (wziqú się) w garść (пол.) - Собраться в кулак (рос.); Опускати (опустити) руки (укр.) — Opuścić ręce (пол.) — Опустить руки (рос.); Заорати (зарити) носом (укр.) - Zaryć поsem (пол.) - Пахать землю носом (рос.); Ламати [собі] голову (укр.) - Lamać sobie głowę (пол.) — Ломать (поломать) голову (рос.) тощо.

Водночас деякі мовні одиниці репрезентують специфічні особливості вербалізації НК, актуалізуючи національні ментальні параметри, напр., комунікативне значення 'чинити комусь опір, виявляючи незадоволення чимось, або бути готовим до захисту' вербалізується ФО Показувати (показати) роги в українській мові та польським фразеологічним еквівалентом Pokazywać (pokazać) $\boldsymbol{r o g i}^{8}$. У російській лінгвокультурі зазначений смисловий еквівалент об' єктивує інший невербальний параметр, що певною мірою розширює значення ФО, порівн.: Показывать зубы: ' 1) огрызаться; 2) перен. проявлять свою злобную или хищническую натуру; обнаруживать готовность к отпору’9.

Відстежити мотивацію таких особливостей видається можливим, звернувшись до етимології досліджуваних МО, зокрема українська паремія Чужсу біду руками розведу, а до свосї ума не приложу, що репрезентує комунікативний

${ }^{7}$ T. Космеда, О. Гоменюк, Т. Осіпова, Короткий украӥнсько-польський словник..., c. 260

9 Малый академический словарь русского языка, [в:] Электронный ресурс: http://www. classes.ru/all-russian/dictionary-russian-academ.htm (25.02.18). 
смисл 'допомогти чужому завжди легше, ніж вирішити власні проблеми' ${ }^{10}$ має формально-семантичний російський еквівалент Чужую беду руками разведу, а к своей ума не прилож⿻ ${ }^{11}$. Російський варіант первісно мав форму Чужню беду бобами разведу..., що грунтувався на старовинному звичаї давніх слов'ян ворожити на долю, використовуючи „воду, вогонь, тварин, рослини (напр., боби) та ін. [...] на сьогодні компонент бобами разведу замінився на руками разведу, тобто відведу, ліквідую нещастя простими рухами рук"' 2 . Відзначимо відносну врівноваженість ментальної опозиції “своє - чуже” всупереч стереотиповому його трактуванню, порівн.: „Слово «чужий» мало в собі концепт «зло» [...] усе, що позитивне, звичайно, є «своїм»" 13 . Натомість у польській фразеології зазначені паремії відповідають варіанту Cudza rana nie boli 3 відцентрованою прагматикою, коли “своє”, особисте переважає, порівн. значення: 'czyjeś nieszczęście nie boli tak bardzo jak swoje'14 ('чуже нещастя не болить так сильно, як своє'). Дослідники зазначають, що ця опозиція має давню традицію [...] i ,подібний аксіологічний процес особливо активно почав спостерігатися в XVIII-XIX ст. в українській та російській культурах, а відповідно — і в мовах. Згадаймо хоча б твір «За двома зайцями» М. Старицького, де лексеми город, городський відображають концепт «позитивне», хоча в контексті це позитивне подається іронічно”"15, наголошуючи й на тому, що в польській мові „наслідком цього було надання значень якості відносним прикметникам"16 3 відповідною прагматичною метою.

Отже, можемо відзначити схожість і відмінність прагматичних оцінних акцентів, що репрезентують ментальні особливості психосприйняття світу.

Процеси комунікації, як відомо, відбуваються під впливом різноманітних комунікативних шумів, серед яких розрізняють фізичний, психічний, семантичний. До групи семантичних шумів у НК належать і оптичні параметри, зокрема артефакти як такі візуальні подразники, що підтримують або руйнують перебіг комунікації. Виходячи 3 широкого розуміння атрефакту як об'єкту, створеного або модифікованого людьми ${ }^{17}$ - одяг, прикраси, мотиваційні предмети - співвідносимо в трьох мовах фразеологічні еквіваленти з невербальними компонентами, де атрефакти відіграють ключову роль, порівн.: Бережи одежу (сукню) знову, а здоров'я змолоду (укр.) - Szanuj suknię nowa, a zdrowie (honor) od młodu (пол.) - Береги платье снову, а здоровье смолоду (рос.); На злодієві й шапка горить (укр.) - Na złodzieju czapka gore (пол.) — На воре шапка горит (рос.); Поганому танцюристові й чоботи заважають (укр.) Zlej tanecznicy zawadza i rabek u spódnicy (пол.) - Плохому танцору башмаки жсмут (ноги мешают, пол кривой і т. д.) (рос.).

Водночас спостерігаємо й деяку непропорційність у репрезентації невербаліки в зазначених мовах. Зокрема традиція відмови під час сватання в укра-

${ }_{10}$ Т. Космеда, О. Гоменюк, Т. Осіпова, Короткий украӥнсько-польський словник..., c. 319 .

${ }^{11}$ Мальй академический словарь русского языка...

12 Там же.

13 Т. Космеда, Аксіологічні аспекти прагмалінгвістики: формування $і$ розвиток категорії оцінки, Львів 2000, с. 18. c. 319 .

14 Т. Космеда, О. Гоменюк, Т. Осіпова, Короткий украйнсько-польський словник...,

15 Т. Космеда, Аксіологічні аспекти прагмалінгвістики ..., с. 19.

${ }^{16}$ Там само.

${ }^{17}$ Современный психологический словарь, сост. и общ. ред. Б. Г. Мещеряков, В. П. Зинченко, Санкт-Петербург 2007, с. 38. 
їнській і польській фразеології репрезентована ФО Давати (підносити, отримати) [печеного] гарбуза (укр.) - Dostać harbuza (пол.) і грунтується на давніх традиціях невербальної комунікації слов'ян, однак зазначений усталений вираз поширений у східній Польщі, що пов'язано з більш тісними контактами цієї частини з Україною, а в західній Польщі він маловідомий. Натомість знавці української і польської лінгвокультур стверджують, що в польській лінгвокультурі поширена інша ФО на позначення тієї самої обрядової традиції, порівн.: Podać komuś czarna polewkę (пол.) - 'частувати чорним супом (супом 3 качиної крові)' чи Postania kosza grochowin (пол.) - 'надсилати кошик горохового лушпиння (непотрібних решток від очищеного гороху)' ${ }^{18}$. Російська традиція відмови під час сватання так само пов'язана з невербальною комунікацією, але сам факт відмови не вербалізується, зокрема, якщо наречений не подобався дівчині, на оглядинах вона могла мовчки вийти з хати, замінити святковий одяг на буденний і повернутися до гостей. Це означало відмову від заміжжя ${ }^{19}$. У російській фразеології не зафіксовано ФО, що репрезентують цей звичай, його збережено на невербальному рівні.

Національну маркованість артефактів та їхню прагматику відзначають також ФО На рушник стати (укр.) - Stanąć (pójść) przed (do) ołtarzem (ołtarza) (пол.) - Идти под венец (рос.), що в українській етнокультурі пов'язано з рушником як символом шлюбної єдності, а в польській та російській - зі святістю ритуалу шлюбу, канонічними переконаннями, що ілюструє культурологічний мотив НК.

Категорія оцінки, як зазначає Т. Космеда, тісно пов'язана з категорією модальності ${ }^{20}$. Дослідниця наголошує на „справедливості поглядів тих учених, які вважають, що в обсяг модальності входять значення, які виражають раціональне та емоційне ставлення мовця до довкілля. Емоційно-експресивна оцінка, яку мотивує мовець, належить до семантики модальності"21. Актуалізуючи спільні ментальні уявлення про шлюб, усі три мови відображають “солідарність" щодо ствердження знакової ролі дружини в “сімейному дуеті", порівн.: Жінка не чобіт: з ноги не скинеш (укр.) - Жена не сапог, намулит, так с ноги не соймешь (рос.) - Żona nie gęśle, pograwszy, nie powiesisz na ścianie (пол.), однак прагматика, зокрема іï оцінний компонент, певною мірою градуюється - від позитивно-бережливого ставлення до жінки, як до музичного інструменту (пол.), — через нейтрально-об'єктивне (укр.) — до негативнозневажливого (рос.) значень.

Установлення еквівалентності мовних одиниць, зокрема фразеологічних, у межах компаративного методу потребує врахування такого явища свідомості, як асоціація, що в мовознавстві продукується як „один із засобів експлікації внутрішнього лексикону й організації його вербальної мережі”"22. На тлі дискусійної проблеми, що стосується типології асоціацій (Ю. Караулов, О. Клименко, Г. Щур, Н. Уфімцева), урахування когнітивного параметра у формуванні класифікаційних ознак становить один із ключових підходів. Напр., асоціатив-

${ }_{18}$ Див. про це: Т. Космеда, О. Гоменюк, Т. Осіпова, Короткий украӥнсько-польський словник..., с. 23-24.

19 А. Перова, Традииии русской свадьбы, обычаи, обряды, ритуаль, [в:] Электронный pecypc: http://www.svadebnye-hlopoty.ru/tradicii-russkoj-svadby-obychai-obryady-ritualy_40.html (08.02.2018).

${ }^{20}$ Т. Космеда, Аксіологічні аспекти прагмалінгвістики..., с. 280.

21 Там само.

${ }^{22}$ О. О. Селіванова, Сучасна лінгвістика : напрями та проблеми..., с. 44. 
на репрезентація конфліктної ситуації Де чарка, там і сварка (укр.) в польській фразеології реалізована ФО Miecz i czarka zgodna parka (пол.), де вербалізуються атрибутивні компоненти, а російський еквівалент омовлює суб'єктнооб'єктні зв'язки, порівн.: Кто часто станет пить, тот часто будет бит (рос.), У Фили пили - его же били (рос.).

Утілення уяви в предметних формах, образах і т. ін. у широкому розумінні репрезентує термін об'єктивація ${ }^{23}$, що, використаний стосовно “суб'єктивного, психічного", або щодо "внутрішньої, імпліцитної, прихованої сутності" 24 , визначає характер ментального мислення. Зокрема ФО з параметром зовнішності (укр. - 1,5\%, пол. - 1\%, рос. - 1,9\%), ілюструють спектр когнітивних образів, які втілюють ментальні уявлення і продукують певні цінності, виявляючи при цьому лінгвокультурну специфіку, порівн.: Як (мов, ніби $\boldsymbol{i}$ m. ін.) корові сідло (укр.) - Pasuje jak świni siodto (wól do karety; pięść do oka) (пол.) — Как корове седло (рос.); У (в) бороді гречка цвіте, а в голові на зяб поорано (укр.) W starym piecu diabel pali (пол.) - Седина в бороду, а бес в ребро (рос.). Оцінну модальність відзначаємо й у таких прикладах: Борода, як у старого, розуму, як у малого (укр.) - Broda mędrcem nie czyni (пол.) - Не в бороде честь, борода и у козла есть (рос.).

Під час аналізу паремійного дискурсу прагматичне наповнення невербальних параметрів ФО може варіюватися, трансформуватися, нівелюватися тощо. Зазначені процеси зумовлюють утворення прагматичних омонімів, що спричиняють мовні й комунікативні порушення взаєморозуміння під час інтерпретації ФО. Напр., відчуття сорому в польській мові омовлюється паремією świecić oczami - 'відчувати сором за когось, чужі помилки, діяння, виховавння'. В українській мові фразеологізм-відповідник ширший за семантикою, порівн.: світити очима (оком, очицями і т. ін.): '1) пильно дивитися; 2) дивлячись, виявляти поглядом почуття гніву, роздратування і т. ін.; 3) не мати чим освітлювати приміщення'. Як бачимо, семантика і прагматика українського виразу не збігається з польським. Окрім того, незначні трансформації, що цілком припустимі в усному мовленні, можуть повністю змінити семантику й прагматику цієї ФО, порівн.: світити в очі - 'лестити, підлещуватися' ${ }^{25}$. У російській лінгвокультурі відсутня ФО такого компонентного складу, натомість зазначений прагматичний смисл репрезентовано ідіомою есть глазами — 'пристально, подобострастно смотреть на кого-либо' 26.

Отже, застосований у цій науковій розвідці порівняльно-зіставний метод, виконуючи композитне завдання, імпліковане порівняльною (компаративною) і зіставною лінгвістиками, що спрямоване на встановлення формальної й прагматичної еквівалентності вербалізаторів невербаліки в споріднених - українській, польській, російській — мовах і дослідження спільних та специфічних комунікативних особливостей НК зазначених етносів, дав змогу виявити такі типи співвідношень ФО з невербальними компонентами:

1) абсолютна еквівалентність;

2) варіативна або неповна відповідність;

${ }^{23}$ Словник украӥнської мови, в 11 томах, ред. колег. І. К. Білодід (голова), П. Й. Горецький та ін., Київ 1970-1980, т. 5, с. 495.

${ }^{24}$ Biкineдія, [в:] Електронний ресурс: https://uk.wikipedia.org/wiki/ об' єктивація (02.03.18).

25 Т. Космеда, О. Гоменюк, Т. Осіпова, Короткий украӥнсько-польський словник усталених виразів..., с. 17-18.

${ }^{26}$ Фразеологический словарь русского литературного языка, [в:] Электронный ресурс: http:// rus-yaz.niv.ru/doc/phraseological-literary-dictionary/index.htm (02.03.18). 
3) відсутність мовної репрезентації вербалізатора НК за наявністю невербальної традиції;

4) градація прагматичних комунікативних смислів;

5) різний характер об'єктивації комунікативного смислу;

5) прагматична омонімія.

Перспективу цієї розробки вбачаємо в поглибленні методики дослідження процесів вербалізації невербаліки, пошуці нових моделей смислотворення, виявленні національних комунікативних стереотипів невербальної поведінки українців.

\section{Список використаної літератури}

Biкineдiя, [в:] Електронний ресурс: https://uk.wikipedia.org/wiki/ об'ективація (02.03.18). Загнітко А. П., Основи дискурсології, Донецьк 2008.

Космеда Т., Аксіологічні аспекти прагмалінгвістики: формування і розвиток категорії оцінки, Львів 2000.

Космеда Т., Гоменюк О., Осіпова Т., Короткий украӥнсько-польський словник усталених виразів: еквіваленти слова, фразеологізми, прислів'я та приказки; за заг. ред. проф. Т. А. Космеди, Познань-Харків-Дрогобич 2017.

Космеда Т., Гоменюк О., Осіпова Т., Українська фразеологія в польській аудиторії: проблеми засвоєння, [в:] Украӥнська мова у світі, зб. матер. IV Міжнар. наук.-практ. конф. 9-10 лист. 2016 р., Львів 2016.

Малый академический словарь русского языка, [в:] Электронный ресурс: http://www. classes.ru/all-russian/dictionary-russian-academ.htm (25.02.18).

Перова А., Традииии русской свадьбы, обычаи, обряды, ритуалы, [в:] Электронный pecypc: http://www.svadebnye-hlopoty.ru/tradicii-russkoj-svadby-obychai-obryadyritualy_40.html (08.02.2018).

Селіванова О. О., Сучасна лінгвістика: напрями та проблеми, Полтава 2008.

Селіванова О., Сучасна лінгвістика: термінологічна енциклопедія, Полтава 2006.

Словник української мови, в 11 томах, ред. колег. І. К. Білодід (голова), П. Й. Горецький та ін., Київ 1970-1980.

Современный психологический словарь, сост. и общ. ред. Б. Г. Мещеряков, В. П. Зинченко, Санкт-Петербург 2007.

Фразеологический словарь русского литературного языка, [в:] Электронный ресурс: http://rus-yaz.niv.ru/doc/phraseological-literary-dictionary/index.htm (02.03.18).

\section{Spysok vykorystanoi literatury [References]}

Vikipediia, [v:] Elektronnyi resurs: https://uk.wikipedia.org/wiki/ obiektyvatsiia (02.03.18). Zahnitko A. P., Osnovy dyskursolohii [Fundamentals of Discourse Studies], Donetsk 2008.

Kosmeda T., Aksiolohichni aspekty prahmalinhvistyky: formuvannia i rozvytok katehorii otsinky [Axiological Aspects of Pragmalinguistics: Formation and Development of Estimation Category], Lviv 2000.

Kosmeda T., Homeniuk O., Osipova T., Korotkyi ukrainsko-polskyi slovnyk ustalenykh vyraziv: ekvivalenty slova, frazeolohizmy, pryslivia ta prykazky [Concise UkrainianPolish Dictioary of Set Expressions: Word Equivalents, Phraseologisms, Proverbs and Sayings], za zah. red. prof. T. A. Kosmedy, Poznan-Kharkiv-Drohobych 2017.

Kosmeda T., Homeniuk O., Osipova T., Ukrainska frazeolohiia v polskii audytorii: problemy zasvoiennia [Ukrainian Phraseology in Polish Audtorium: Problems of Learning], [v:] Ukrainska mova u sviti, zb. mater. IV Mizhnar. nauk.-prakt. konf. 9-10 lyst. 2016 r., Lviv 2016. 
Malyj akademicheskij slovar russkogo jazyka [Small Academic Dictionary of the Russian Language], [v:] E'lektronnyj resurs: http://www.classes.ru/all-russian/dictionaryrussian-academ.htm (25.02.18).

Perova A., Tradicii russkoj svadby, obychai, obryady, ritualy [Traditions of Russian Wedding, Customs, Rites, Rituals], [v:] E’lektronnyj resurs: http://www.svadebnye-hlopoty. $\mathrm{ru} /$ tradicii-russkoj-svadby-obychai-obryady-ritualy_40.html (08.02.2018).

Selivanova O. O., Suchasna linhvistyka: napriamy ta problemy [Modern Linguistics: Directions and Problems], Poltava 2008.

Selivanova O., Suchasna linhvistyka: terminolohichna entsyklopediia [Modern Linguistics: Terminological Encyclopedia], Poltava 2006.

Slovnyk ukrainskoi movy [The Ukrainian Language Dictionary], v 11 tomakh, red. koleh. I. K. Bilodid (holova), P. Y. Horetskyi ta in., Kyiv 1970-1980.

Sovremennyj psihologicheskij slovar' [Modern Phylosophical Dictionary], sost. i obshh. red. B. G. Meshheryakov, V. P. Zinchenko, Sankt-Peterburg 2007.

Frazeologicheskij slovar' russkogo literaturnogo jazyka [Phraseological Dictionary of The Russian Literary Language], [v:] E’lektronnyj resurs: http://rus-yaz.niv.ru/doc/ phraseological-literary-dictionary/index.htm (02.03.18). 